\title{
Design and Investigation of Optimal Cooling System for Operative Performance of PEM Fuel Cell
}

\author{
Abdullah A. Alshorman, Ph.D.
}

Al-Balqa’ Applied University- Al-Huson University College - Mechanical Engineering Department, P.O.Box 50 - Al-Huson 19117- Irbid - Jordan,

\section{Abstract}

Proton exchange membrane fuel cell (PEMFC) is thermochemical-electrical device for clean energy utilization as a practical renewable energy resource. Among several types of fuel cells PEMFC has compact size, wide applications, integrated structure and controlled operation conditions for realistic performance. PEMFC operates within temperature range of $\left(25-80^{\circ} \mathrm{C}\right)$ and slightly above, which need special cooling system to maintain harmless thermal operation of the cell.

In this simulation study a functional cooling system for PEMFC is proposed, designed and investigated for best PEMFC performance and efficiency. This system is examined for energetic outcome of PEMFC using different materials, geometry, working fluids, operating conditions, and thermal properties of cooling fluids.

The results reveals that greatest efficiency of cooling system of PEMFC is associated to higher flow rate and thermal properties of cooling fluid like specific heat $\left(\mathrm{C}_{\mathrm{p}}\right)$ and convection heat transfer coefficient (h), in addition to thermal emissivity $(\boldsymbol{\varepsilon})$, thermal conductivity (k). Furthermore, the best cooling system efficiency range was $60 \%$ to $80 \%$ when Argon was used, and $40 \%$ to $55 \%$ for water, while the least range was $17 \%$ to $22 \%$ when air was used as a cooling medium.

Key words: PEM fuel cell, cooling system, efficiency, thermal properties

* Corresponding Author - Dr. Abdullah A. Alshorman, Associate Professor, Email: alshormana@asme.org, Tel: 00962-775613175 Fax: 00962-2-7010397

\section{Introduction}

Proton electrolyte exchange fuel cell (PEMFC) is a clean energy resource with relatively no emission pollutants such that it converts the chemical energy of its main fuel (the hydrogen) in to electricity at relatively low voltage output rate. Structurally, PEMFC consists of three major layers stack and other subsequent sub layers to support the cell effectiveness, current density and overall cell efficiency. These layers are the hydrogen port (the cathode), the electrolyte membrane in the middle, and the oxygen port (the anode) at the other side of the fuel cell.

Normally, PEMFC operates at moderate to high temperature range which should not exceed (80-85 ${ }^{\circ} \mathrm{C}$ ) to avoid any thermal stress within its inside structure and therefore avoid any mechanical damage of the cell, and to control the moisture contents rate of cell membrane.

PEMFC has different ranges of applications like small electric and electronic devices of low to moderate voltage rat, transportation, battery replacement and electric auxiliary systems of power generation.Currently there are many different fuel cell types with diverse design, structure, power capacity and industrial applications with wide range of operating temperature ranges [1-3].

\section{How Fuel cell works}

There are many types of fuel cells, but they all consist of an anode, a cathode and an electrolyte that allows charges to move between the two sides of the fuel cell as shown in figure (1). 
As shown in figure 1, hydrogen (the fuel) is supplied at certain pressure, temperature and mass flow rate to the anode side of PEMFC while oxygen is fed to the cathode side. Both elements react through the membrane and its lining catalyst sub layer to generate electrical power at about 07-0.9 volts, heat and water as products of these chemical reactions. However, to maximize the PEMFC output voltage, many cells are stacked in series to meet the demand rate of power applications and requirements.

The energy efficiency of a fuel cell is generally between $40-60 \%$, or up to $85 \%$ efficient in cogeneration if waste heat is captured for use [4].
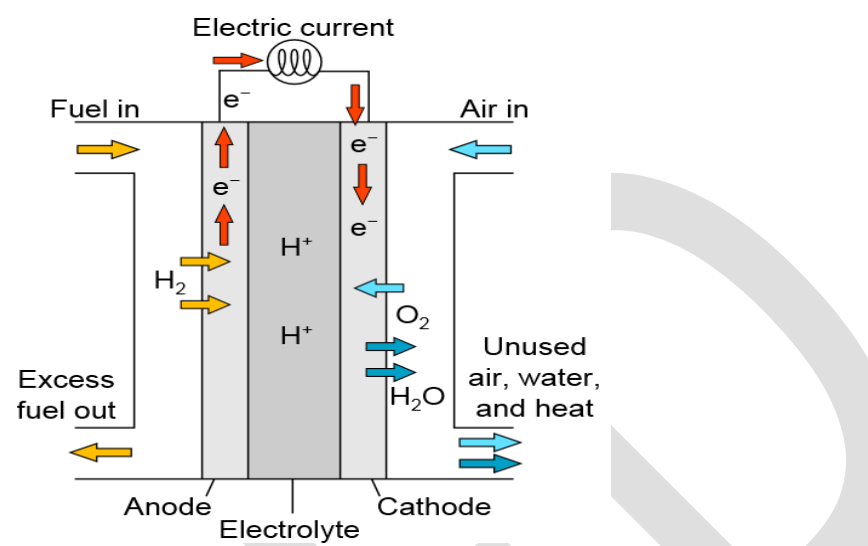

Figure (1) how PEM fuel cell work [4]

\section{Cooling system of PEM fuel cell}

Heat is one major products of PEMFC as a result of inside chemical reactions and power generation of the fuel cell, so it is an essential task to cool the thermal path of PEMFC using operational cooling system.

There are varieties of ways by which PEM fuel cell stack can be cooled depending upon the size and application of the stack [5-8]. Figure 2 shows schematically the differentcooling methods used for PEM fuel cell stacks in general. These commonly used coolingmethods for PEM fuel are (1) cooling with cathode air (2) cooling with separate air (3) liquid cooling (4) evaporative cooling and (5) cooling with heat spreaders [9]. The proposed cooling method in this study is simulated using air, gas and liquid as cooling medium as explained below.
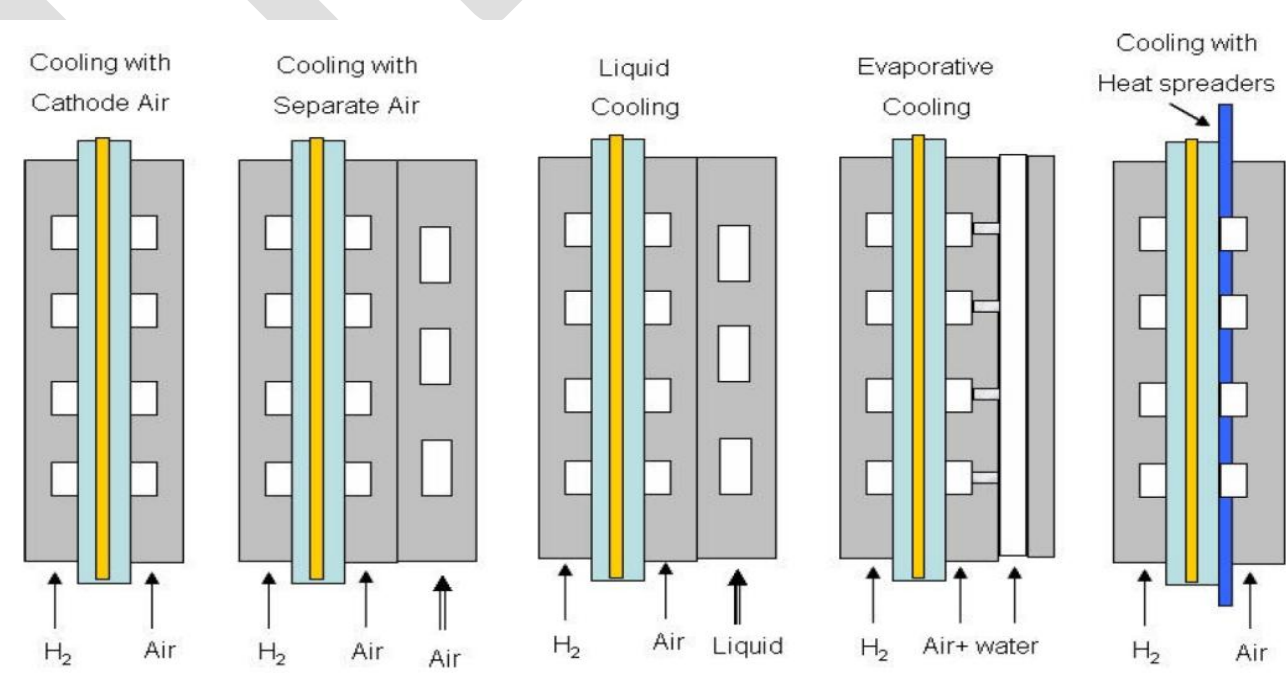

Figure (2) : Schematic of different cooling methods for unit PEM fuel cell [9] 


\section{Mathematical modeling of PEM fuel cell cooling system}

\section{Method of Analysis}

In this modeling and simulation study, the design and investigation processes of PEM fuel cooling system were performed based on the following considerations:

1. Fundamentals: The cooling system of PEM fuel cell is simulated as a surrounding casing similar to the fuel cell geometry. Functionally, the mathematical modeling was developed using the mathematical models of PEM fuel cell and its associated heat transfer principles [11-13], while the computerized models were developed using special developed MATLAP ${ }^{\circledR}$ functions to simulate the thermofluid situations of cooling system for PEM fuel cell. Essentially, this simulation analysis inspected the scaling role of effective parameters of the cooling system like geometry, materials, operating conditions and thermal properties of working fluids

2. The cooling system was investigated for optimal working efficiency of cooling system

3. The cooling system was investigated to control the thermal balance of the PEM fuel cell and absorb the excess heat generated during normal operation of the cell using different materials for the cooling system with their associated thermal properties. Specifically, the materials used were copper, iron and stainless steel.

4. The cooling system efficiency is scaled using several types of working fluid such as air, argon, oil and water to enhance the PEM fuel cell efficiency according to their thermo-hydrodynamical properties like specific heat, thermal conductivity, thermal emissivity, convection heat transfer coefficient, and density.

5. The effects of operating conditions ofPEM fuel cell such as, pressure and temperature were investigated for different types of working fluids at different mass flow rate

Furthermore, the following assumptions were considered during this thermal simulation analysis:

1. Steady-state conditions.

2. Negligible temperature variations within the fuel cell.

3. Fuel cell is placed in large surroundings.

4. Edges of the fuel cell are well insulated.

5. Negligible energy entering or leaving the control volume due to gas or liquid flows.

\section{Mathematical modeling of cooling system for PEM fuel cell}

Principally the main operating major layers of PEM fuel cell are cathode (oxygen side), electrolyte membrane (ions transport and power generation side in the middle) and anode (hydrogen side) as shown in figures 1 and 2. The moisture rate of the middle membrane should be controlled to enable for normal passing of ions through it. Also the product liquid water at the cathode material should be systematized to have it as water vapor to enable for normal passing of oxygen to reach the reaction locations. This indicates the so importance of fuel cell temperature $\left(\mathrm{T}_{\mathrm{c}}\right)$ controlling to meet the saturated vapor conditions at the cathode side.

For a given set of $\mathrm{H}_{2}$ and air inlet flow rates and use membrane electrode assembly (MEA), the fuel cell generates $p=I . E_{c}$ electrical power, associated with a cell voltage $\left(E_{c}\right)$ and electric current (I).Saturated vapor conditions exist in the fuel cell, corresponding to $T_{C}=T_{\text {sat }}$, The overall electrochemical reaction is exothermic and the corresponding thermal generation rate of $\dot{E}_{g}$, must be removed from the fuel cell by convection and radiation. The ambient and surrounding temperatures are $T_{\infty}=T_{\text {sur }}$, and the relationship between the cooling air velocity $(V)$ and the convection heat transfer coefficient, $h$, is [10]: 


$$
h=10.9 W \cdot \frac{S^{0.8}}{m^{2.8}} \cdot \mathrm{k} \times V^{0.8}
$$

Where $(V)$ has units of $\mathrm{m} / \mathrm{s}$.

Now To determine the required cooling air velocity, at firstan energy balance on the fuel cell should be performed. With $\dot{E}_{\text {in }}=\dot{E}_{\text {out }}, \quad \dot{E}_{\text {in }}=0$ and $\dot{E}_{\text {out }}=\dot{E}_{g}$, generation energy $\left(\dot{E}_{g}\right)=q_{\text {conv }}+q_{\text {rad }}$

Such that

$$
\mathrm{q}_{\mathrm{rad}}=\varepsilon \sigma \mathrm{A}\left(\mathrm{T}_{\mathrm{c}}^{4}-\mathrm{T}_{\text {sur }}^{4}\right)
$$

\section{Where:}

$\varepsilon=$ The emissivity of the exterior surface of fuel cell.

$\mathrm{A}=$ Area of fuel cell $\left(\mathrm{m}^{2}\right)$.

$\sigma=$ Stefan - Boltzmann constant and equal $=5.67 \times 10^{-8} \mathrm{~W} /\left(\mathrm{m}^{2} \cdot \mathrm{K}^{4}\right)$

$\mathrm{T}_{\mathrm{c}}=$ Fuel cell Temperature $\left({ }^{\circ} \mathrm{C}\right)$

$\mathrm{T}_{\text {surr }}=$ The surrounding Fuel Cell Temperature $\left({ }^{\circ} \mathrm{C}\right)$

While $q_{c o n v}$ equal:

Where:

$$
q_{\text {conv }}=\mathrm{hA}\left(T_{c}-T_{\infty}\right)
$$

$\mathrm{h}=$ convection heat transfer coefficient $\left(\mathrm{W} / \mathrm{m}^{2} \mathrm{~K}\right)$

$\mathrm{A}=$ Area of fuel cell $\left(\mathrm{m}^{2}\right)$

$T_{C}=$ Fuel cell temperature $\left({ }^{\circ} \mathrm{C}\right)$

$T_{\infty}=$ Ambient temperature $\left({ }^{\circ} \mathrm{C}\right)$

Using eqn.1 for convection heat transfer coefficient (h) and substitute into eqns. (3) to get an expression for convection heat transfer coefficient rate $\left(\mathrm{q}_{\mathrm{conv}}\right)[11]$ :

$$
q_{\text {conv }}=\left(10.9 V^{0.8}\right) A\left(T_{C}-T_{\infty}\right)
$$

Consequentlythe cooling air (or any cooling fluid) velocity equal to :

$$
\mathrm{V}=\left[\frac{q_{c o n v}}{10.9 \cdot A\left(T_{c}-T_{\infty}\right)}\right]^{1.25}
$$

\section{Other working fluids for PEM fuel cell cooling system}

As an alternative approach, this model was designed to use different working fluids (other than air) in the cooling system of PEM fuel cell to operate in acceptable range of temperature aiming at high efficiency of PEM fuel cell. Accordingly, the thermal balance of PEM fuel cell and its cooling system is addressed as heat source (the fuel cell) and heats sink (the cooling system) as explained in figure 4 
below. In this arrangement the heat analysis and thermal balance of the current situation are explained as following [11-15]:

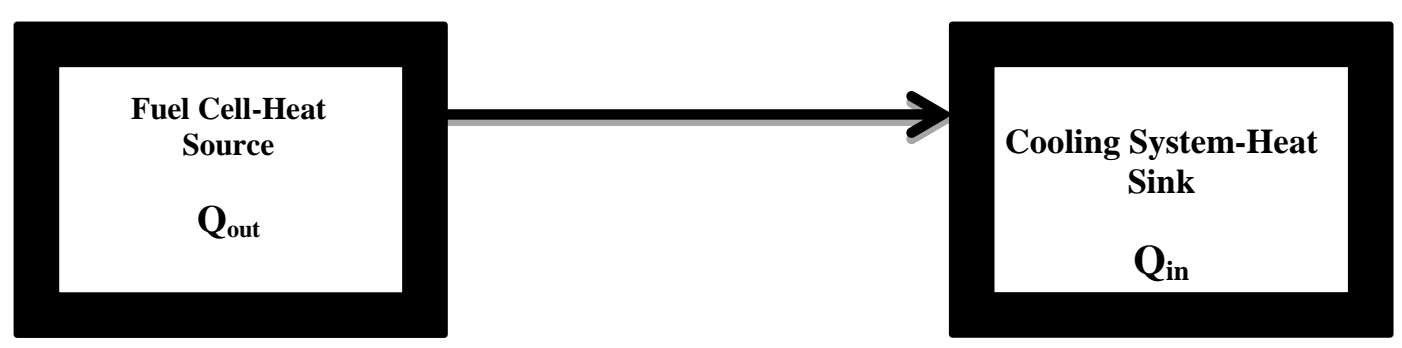

Figure (3) PEM fuel cell and its cooling system as heat source and heat sink arrangement

The totalthermal output heat generated within the PEM fuel cell $\left(\mathrm{Q}_{\text {out }}\right)$ that is being transferred to the cooling system around the fuel cellis given as following:

$$
Q_{\text {out }}=\dot{m} c_{p} \Delta T_{1}(6)
$$

\section{Where}

$Q_{\text {out }}:$ Heat transfer rate out fuel cell $(\mathrm{W})$.

$\dot{m}$ : Mass flow rate for cooling fluid $(\mathrm{kg} / \mathrm{s})$.

$c_{p}$ : Specific heat capacity of cooling fluid ( $\left.\mathrm{kj} / \mathrm{kg} . \mathrm{k}\right)$.

$\Delta T_{1}$ : Temperature difference between cooling system and surrounding.

Practically the thermal balance between the PEM fuel cell and its surrounding cooling system requires that the thermal output heat generated within the PEM fuel cell ( $\mathrm{Q}_{\text {out }}$ ) is totally transferred in to cooling system as $\left(\mathrm{Q}_{\text {in }}\right)$ in forms of convection $\left(\mathrm{Q}_{\text {conv }}\right)$, radiation $\left(\mathrm{Q}_{\mathrm{rad}}\right)$ and conduction $\left(\mathrm{Q}_{\text {cond }}\right)$ as explained below:

$$
Q_{\text {in }}=Q_{\text {conv }}+Q_{\text {rad }}+Q_{\text {cond }}(7)
$$

Where

$Q_{\text {in }}$ : Heat transfer rate that enter the cooling system of PEM fuel cell (W)

$Q_{\text {conv }}:$ Heat transfer rate by convection (W)

$Q_{\text {rad }}:$ Heat transfer rate by radiation (W)

$Q_{\text {cond }}:$ Heat transfer rate by conduction (W)

Each heat transfer mode within this thermal environment could be expressed using associated thermal and hydrodynamical effective parameters of PEM fuel cell and its cooling system as in the following method:

$$
Q_{\text {rad }}=\sigma \varepsilon \mathrm{A}\left(T_{f}^{4}-T_{C S}^{4}\right)
$$

Where

$Q_{\text {rad }}:$ Heat transfer rate by radiation (w)

$\varepsilon$ : Thermal emissivity of working fluid within the cooling system

$\sigma$ : Stefan-Boltzmann constant $=5.670367 \times 10^{-8} \mathrm{~W} \mathrm{~m}^{-2} \mathrm{~K}^{-4}$

A: Area of fuel cell $\left(\mathrm{m}^{2}\right)$

$T_{C}$ : Temperature of cooling system $(\mathrm{K})$

$T_{f}:$ Temperature of fuel cell $(\mathrm{K})$

$Q_{\text {conv }}=\mathrm{h} \mathrm{A}\left(T_{f}-T_{c}\right)(9)$

Where

$\mathrm{h}$ : convection heat transfer coefficient of the working fluid $\left(\mathrm{w} / \mathrm{m}^{2} \cdot k\right)$ 
A: Area of fuel cell $\left(\mathrm{mm}^{2}\right)$.

$T_{C S}$ : Temperature of cooling system (k).

$T_{f}$ : Temperature of fuel cell (k).

$$
Q_{\text {cond }}=\frac{\mathrm{K} \mathrm{A} \Delta T_{1}}{t}(10)
$$

Where:

$Q_{\text {cond }}:$ Heat transfer rate by conduction (W)

A: Area of fuel cell $\left(\mathrm{mm}^{2}\right)$.

$\Delta T_{1}$ : Temperature difference between cooling system and surrounding.

$\mathrm{K}$ : Thermal conductivity of material $\left(\mathrm{W} / \mathrm{m}^{2} . \mathrm{K}\right)$

$\mathrm{t}$ : Thickness of the box (mm).

Then the cooling system efficiency $\left(\eta_{\mathrm{cs}}\right)$ may be expressed as following:

$\eta_{c S}=\frac{Q_{\text {out }}}{Q_{\text {in }}}(11)$

$\eta_{c S}=\frac{Q_{\text {thermal }}}{Q_{\text {conv }}+Q_{\text {rad }}+Q_{\text {cond }}}$

$\eta_{c S}=\frac{\dot{m} c_{p} \Delta T_{1}}{\sigma \varepsilon \mathrm{A}\left(T_{f}^{4}-T_{c S}^{4}\right)+\mathrm{hA}\left(T_{f}-T_{c S}\right)+\frac{\mathrm{KA} \Delta T_{1}}{t}}(13)$

\section{The computerized simulationmodel}

The above mathematical modeland its related effective parameters were prescribed, coded, flowcharted, listed to build up an effective and sophisticated computerized model using MATLAB ${ }^{\odot}$ programing functions to execute comprehensive simulation analysis using different types of working fluids as a coolant medium for PEM fuel cell cooling system,. This computerized model was operated to cover the entire fields of technical investigations of the current study as presented below in results and discussion divisions.

\section{Results and Discussion}

In this investigation work, four working fluids were inspected as a cooling medium for cooling system of PEMFC, such that the efficiency of this cooling system was determined and scaled according to the thermal combination role and the thermal properties of these working fluids. These working fluids are air, water, argon and engine oil.

The major analysis emphasized on calculating of PEMFC cooling system efficiency under effects of operating conditions, materials and geometrical parameters of cooling system in addition to the effects of thermal properties of coolants materials.

The results of these investigations revealed wide range of numerical values of cooling system effectiveness, mass flow rate, area and thickness of materials of the PEMFC cooling system as elucidated through figures 4 to 13 below.

\section{The effect of operating conditions of cooling system: Mass flow rate of working fluid (m), operating temperature ( $T$ ) and working fluid type}

The effects of mass flow rates of working fluids and their operating temperature are explained by figures 4 to 8 for the different working fluid used in investigation. It is clear that the mass flow rate of working fluid of the PEMFC cooling enhances its efficiency at different rates according to the nature and properties of fluid as shown in figures (4-7). Obviously the highest system efficiency is associated to the gaseous nature fluids (air and argon) while the opposite for liquefied working fluids (water and oil). 
For air the system efficiency was of highest range of $40 \%$ to $100 \%$, while this range was $35 \%$ to $70 \%$ when argon is used as presented in figures 4 and 5 . On the other hand, the low system efficiency ranges was $17 \%$ to $35 \%$ for water and the lowest for engine oil of $12 \%$ to $25 \%$. This behavior is due to active role of mass flow rate $(\mathrm{m})$ of working fluid in the thermal capacity of fluid and its ability to gain energy that generated from the PEFC, also the combination effects of thermal and dynamical properties of working fluids in the three modes of heat exchanging between PEMFC and its surrounding cooling system [16-18].

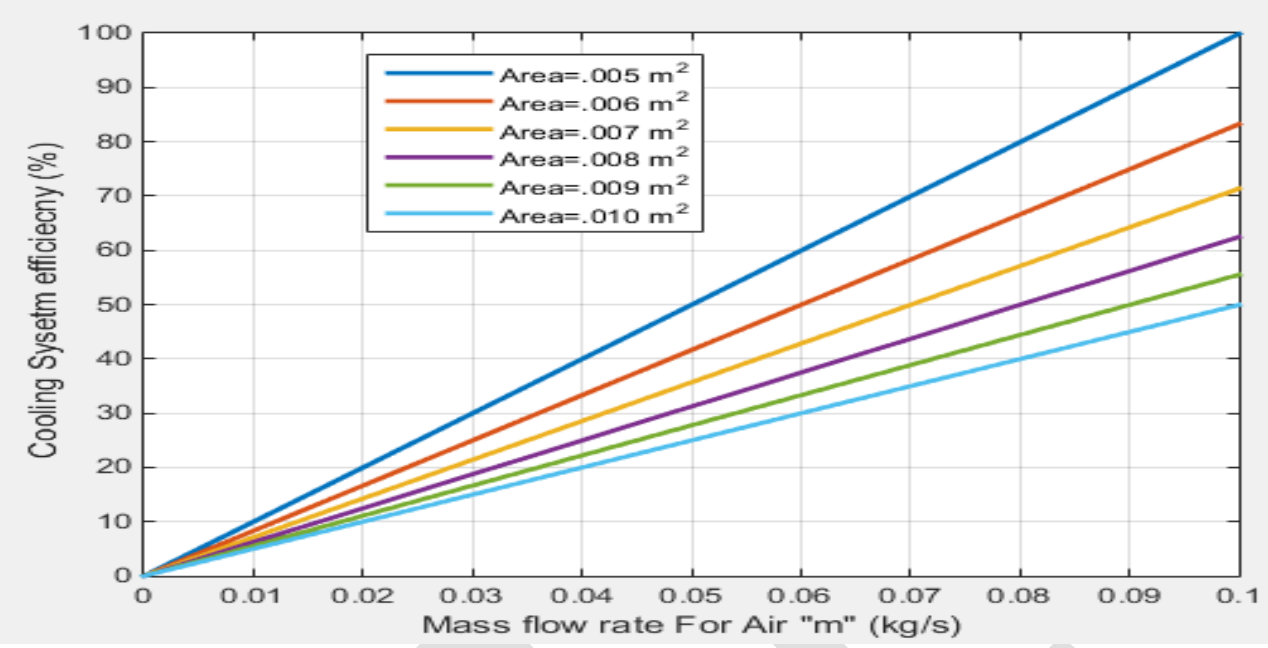

Figure (4)The effect of Mass flow rate for Air and Area of the box on PEMFC cooling system efficiency

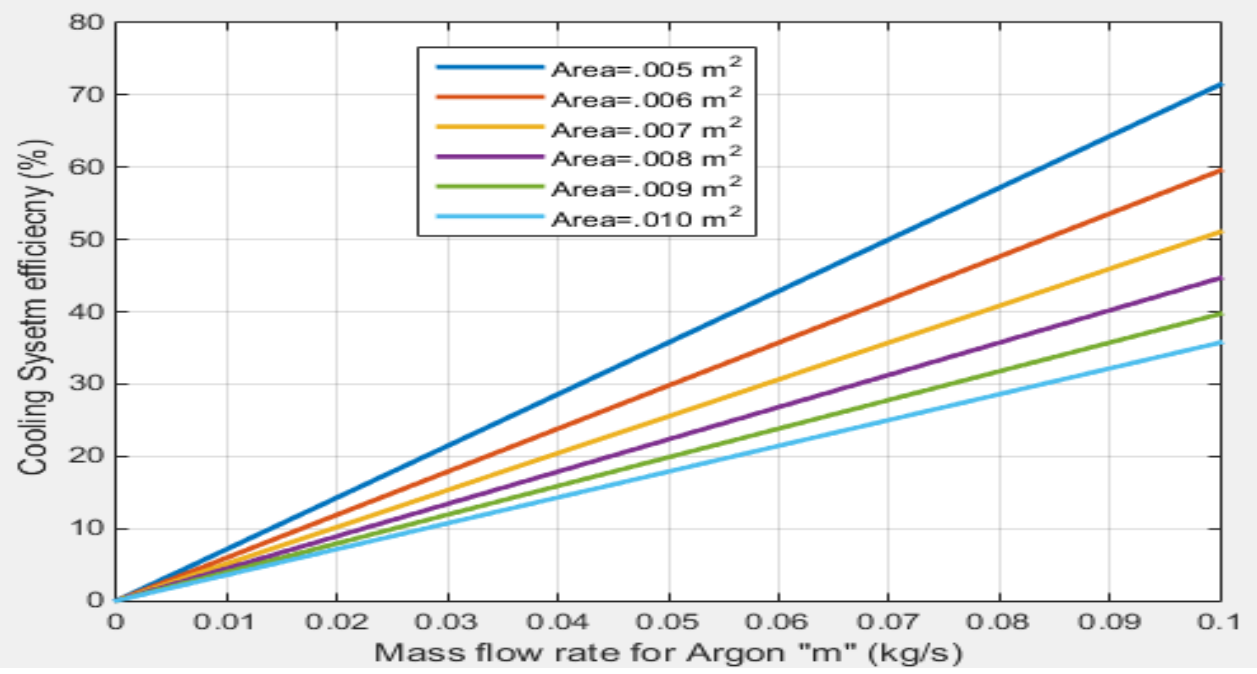

Figure(5)The effect of mass flow rate for Argon and Area of the box on PEMFC cooling system efficiency

However the surface area of PEMFC cooling system has opposite effect on system efficiency such that higher system efficiency is related to minimum system surface area. This could be explained because the small nature size of PMFC and the major heat transfer rate within the PEMFC cooling system is generally occurs by convection. Moreover, the area parameter is common in both conduction and convection heat transfer modes out of the system where the efficiency of it is inversely affected by the surface area of the system according to equation 13 . 


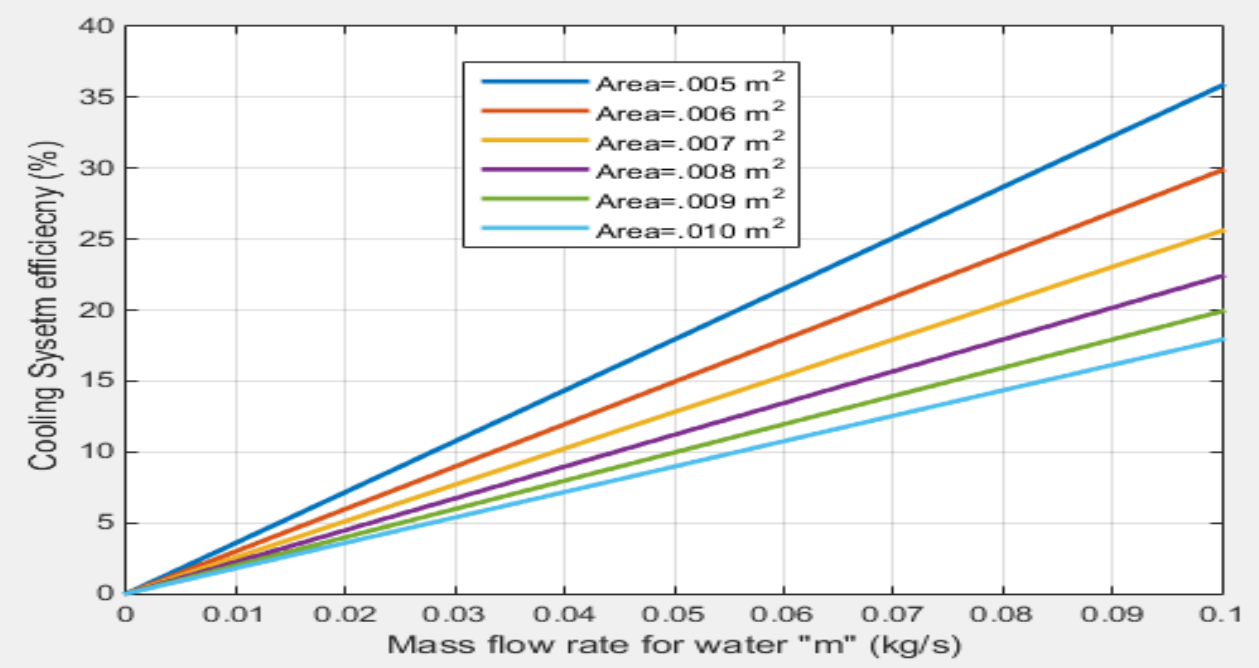

Figure (6) The effect of mass flow rate for Water and Area of the box on PEMFCcooling system efficiency

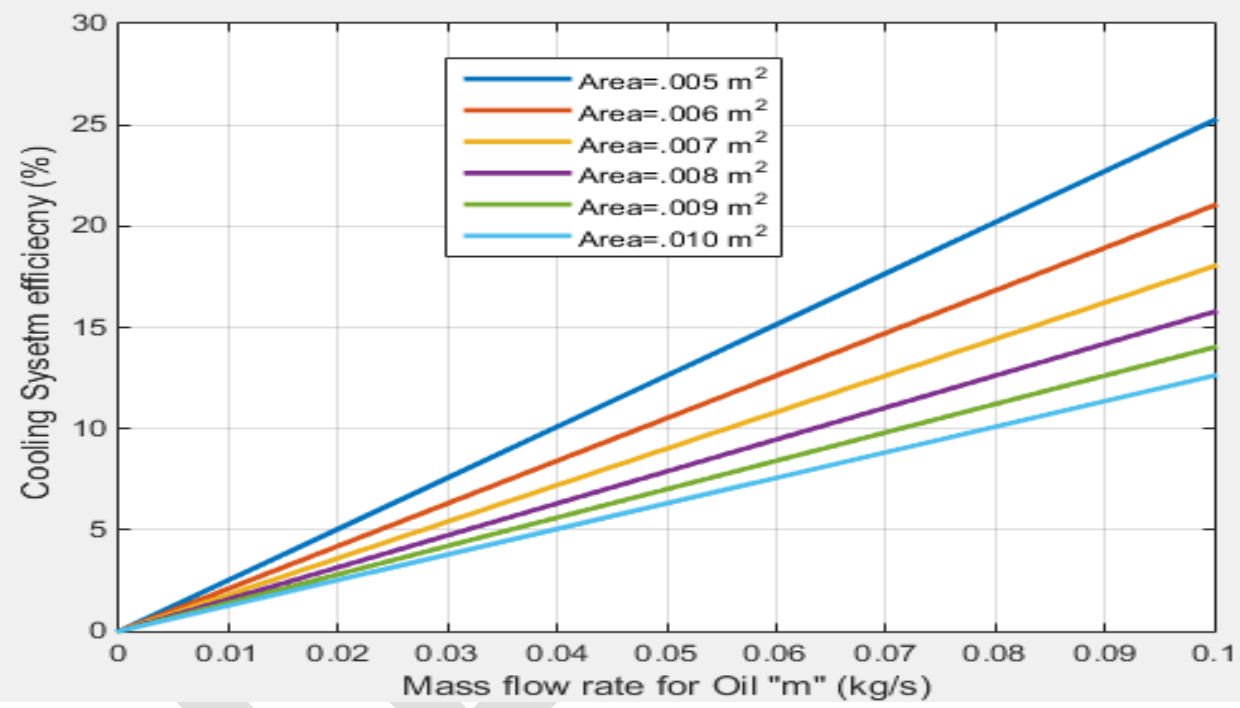

Figure (7)The effect of mass flow rate for Oil and Area of the box on PEMFCcooling system efficiency

The low system efficiency when water and oil were used as a cooling fluid is due to relatively high thermal conductivity $(\mathrm{k})$ and comparative higher density and dynamic viscosity of these fluids when compared to gaseous fluids.

Figure 8 shows that the efficiency of PEMFC cooling system declines as the temperature of PEMFC increases for all working fluids excluding argon which has the same value at any operating temperature within the range of investigation (290-370 K). Tis behavior is related to the thermal and hydrodynamical properties of working fluids that include specific heat $\left(\mathrm{C}_{\mathrm{p}}\right)$, thermal emissivity $(\varepsilon)$, thermal diffusivity $(\alpha)$ and thermal conductivity $(k)$ in addition to density $(\rho)$ and dynamic viscosity $(\mu)$ of these fluids. Furthermore, the operating temperature of PEMFC strongly related to the all types of heat transfer within the thermal environment of the fuel cell and its cooling system like thermal heat generated inside PEMFC, convection, radiation and conduction heat transfer as explained in mathematical model equations. 


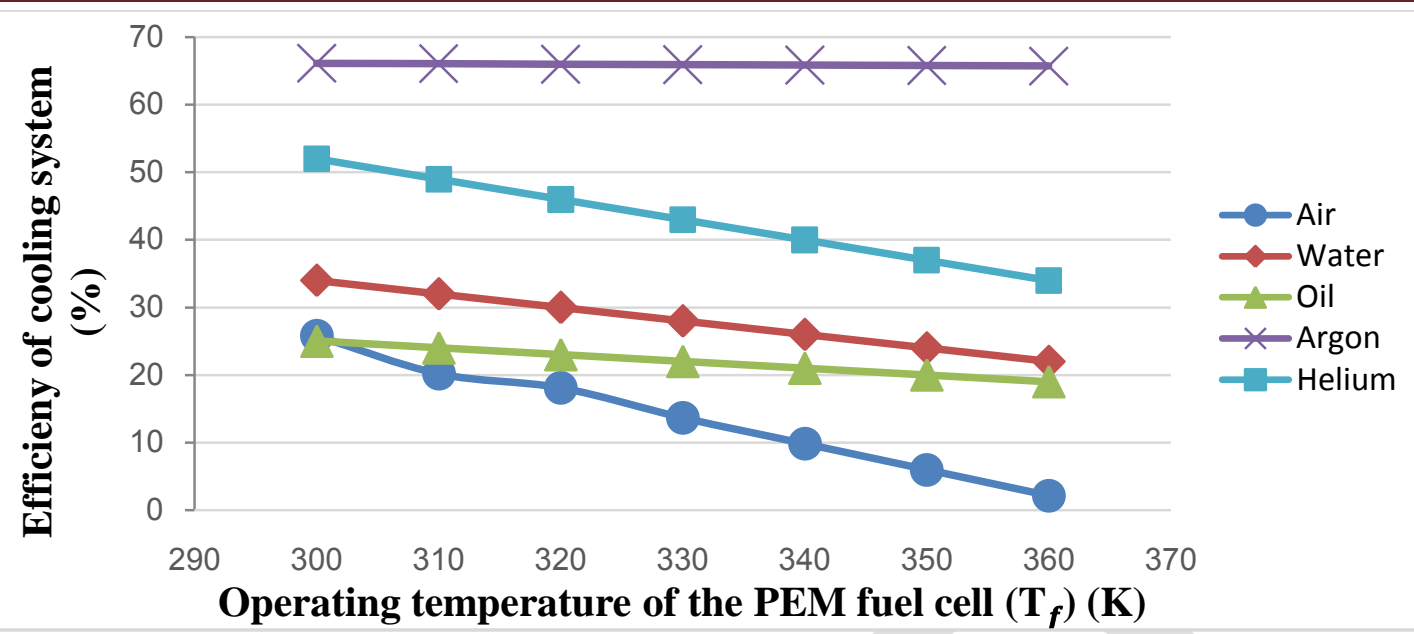

Figure (8)The effect of fluid type and operating temperature on PEMFCcooling system efficiency

It could be noted from figure 8 that the best cooling system efficiency is achieved using argon with a constant system efficiency of about of $70 \%$ over the entire operating temperature rang. This is due to its relative low specific heat, low thermal conductivity, low convection heat transfer coefficient and its stable physiochemical behavior as nonflammable inert gas. Another inert gas tested was helium with a system efficiency range of $52 \%$ at room temperature and $34 \%$ at relatively high temperature of $360 \mathrm{~K}$. On the other hand, all other working fluids provided low cooling system efficiency values ranging between $(25 \%-33 \%)$ at $300 \mathrm{~K}$ and (18-22\%) at high temperature except air which gave $2 \%$ efficiency at $350 \mathrm{~K}$. These findings suggest that argon may be the best working fluid for PEMFC cooling system over the ranges of temperature within the thermal path of operation of PEMFC.

2. The effect of materials and geometrical parameters of the cooling system: Surface area (A) and thickness (t)

To check the effect of materials and geometrical parameters of PEMFC cooling system on its effectiveness, three types of materials are tested at different surface area and thicknesses. These materials are stainless steel, copper and iron where each of them has its own thermal and physiochemical characteristics and behavior according to the thermo-chemo-mechanical environment of the PEMFC cooling system.

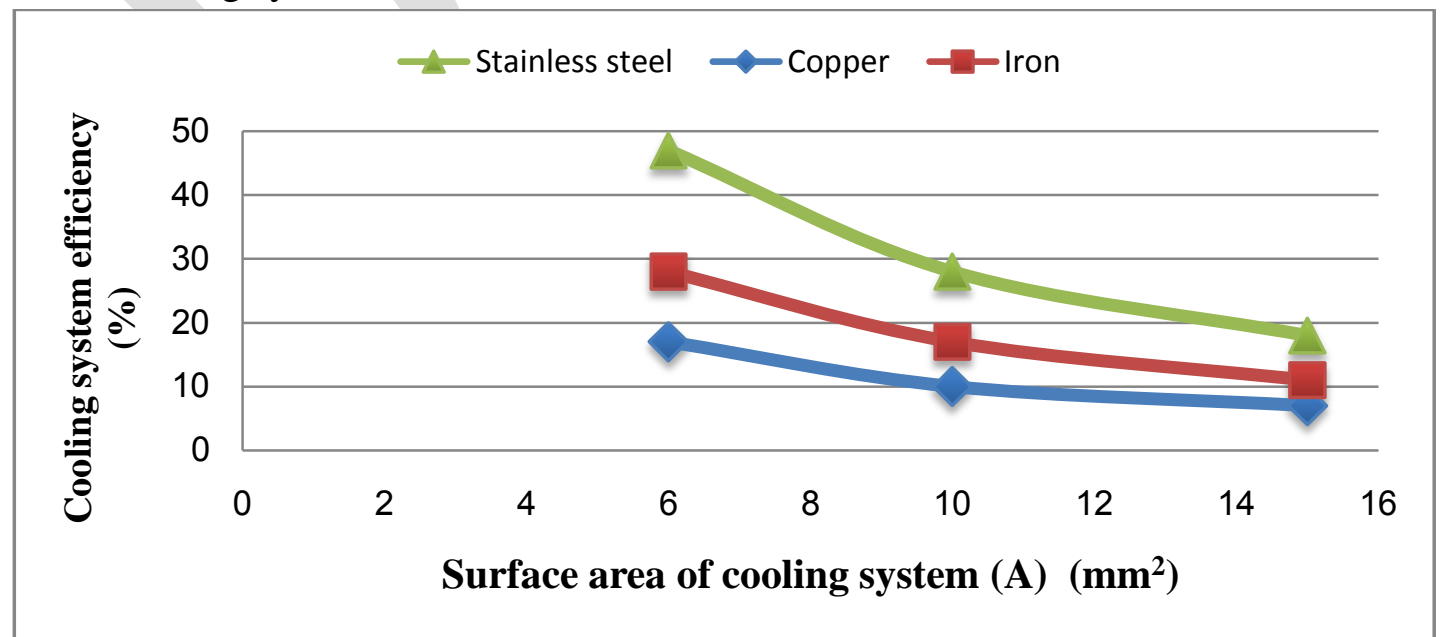

Figure (9) The effect of surface area (A) of PEMFC cooling system on its efficiency for different materials 
The results of this analysis are explained in figures 9 and 10. It can be noted that when air is a system coolant there is an inverse relationship between the area of PEMFC cooling system (A) and its efficiency within an efficiency lower limit of $7 \%$ with iron and higher limit of $46 \%$ with stainless steel as shown in figure 9. This is because the area (A) of cooling system is a common parameter in both conduction and convection heat transfer modes within the cooling system and this will increase the dissipation of heat out of the PEMFC toward the surrounding cooling system which inversely proportional to the cooling system efficiency.This indicates that the smaller size of PEMFC cooling system the higher of its efficiency will be attained due to the nature structure, size, output power and current density of PEMFC.

The higher cooling system efficiencyis obtained using stainless steel as a structural material of PEMFC cooling system. The system efficiency ranges between $46 \%$ at medium surface area to $17 \%$ at higher surface area. This is due to relatively low thermal conductivity $(\mathrm{K})$, high specific heat $\left(\mathrm{C}_{\mathrm{p}}\right)$ and convection heat transfer coefficient $(\mathrm{h})$ of stainless steel in addition to itshigh thermal emissivity of it in comparison to iron and copper. The medium efficiency range was $10 \%$ to $28 \%$ for iron and the lowest was for copper at $7 \%$ to $17 \%$ within the surface area range.

These results suggest that stainless steel is the best recommended material for PEMFC due to its physiochemical and thermal properties in addition to its operative corrosion resistance.

Figure 10 shows that the increase of material thickness (t) of PEMFC cooling system enhances the cooling system performance efficiency at different scales ranging between 5\% at low thickness to $80 \%$ at higher thickness. This can be explained due to the role of material of cooling system in the activation of thermal resistance of material which lowering the conduction heat transfer to the cooling system and increase its efficiency. Also high thermal conductivity of material (k) like copper will give the same effect as the material thickness $(t)$ in activation of thermal resistance of cooling system and consequently lowering conduction heat transfer rate from PEMFC in to surrounding cooling system which improve the system efficiency as presented in figure 10. These findings indicates that the material of PEMFC cooling system should has high thermal conductivity (k) with relatively medium to high thickness ( $\mathrm{t}$ ) like copper or smaller material thickness if this material has low to medium thermal conductivity like stainless steel or iron.

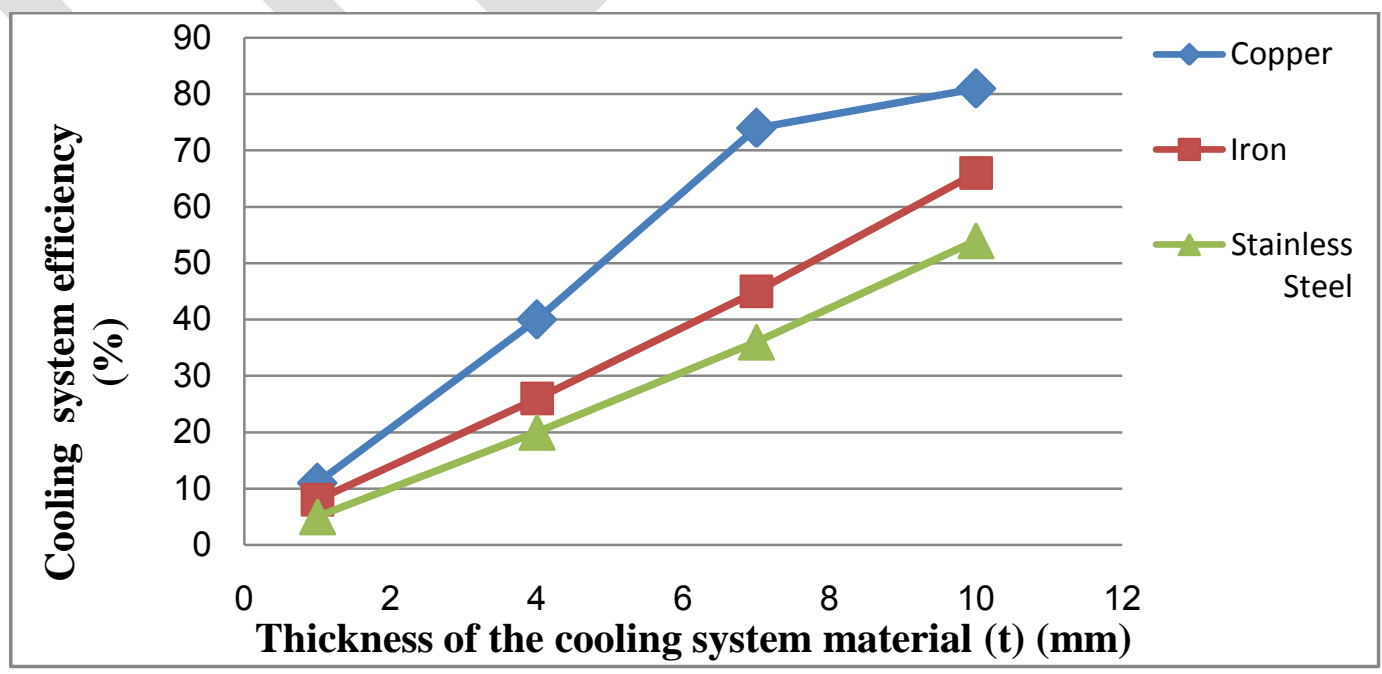

Figure (10) The effect of material thickness (t) of PEMFC cooling system on its efficiency for different materials 


\section{Conclusion}

An operative PEMFC cooling system simulation model was suggested and investigated using different working fluids, materials, geometrical parameters and operating conditions. The best cooling system performance was achieved using gaseous working fluid like air and argon rather than liquid cooling medium like water and engine oil. Moreover, the growth in both mass flow rate of PEMFC cooling medium $(\mathrm{m})$ and its material thickness $(\mathrm{t})$ have an improving effect on cooling system efficiency, while surface area and operating temperature of cooling system have an opposite effect for all working fluid investigated except argon, who gives high constant system efficiency of about $70 \%$ over the operating temperature range.

Particularly, the PEMFC cooling system efficiency ranges from (5\%-10\%) at its low limit to (75\%$80 \%$ ) for high boarders according to the operating conditions and geometrical structure of the cooling system

The results indicate that the best PEMFC cooling system efficiency (i.e., more than $65 \%$ ) can be achieved using small surface area with high possible material thickness of cooling system, good matched thermal properties of working fluid and low to medium possible operating temperature (i.e, not more than $330 \mathrm{~K}$ ). On the other hand it is possible to get high cooling system efficiency of $70 \%$ for the all temperature range including high values using argon as a cooling fluid due to its relative low specific heat, low thermal conductivity, low convection heat transfer coefficient and its stable physiochemical behavior as nonflammable inert gas.

\section{References}

1. Nishimura A. et. al., (2015), Temperature Distributions in Single Cell of Polymer Electrolyte Fuel Cell Simulated by an 1D Multi-plate Heat-Transfer Model and a 3D Numerical Simulation Model,--Journal of Energy and Power Engineering 9,687-704

2. Schweiss R.,(2016), Benefits of Membrane Electrode Assemblies with Asymmetrical GDLConfigurations for PEM Fuel Cells, Fuel Cells 16, No. 1, 100-106

3. Imen S. J., and Shakeri M., (2016), Reliability Evaluation of an Open-Cathode PEMFC at Operating State and Longtime Vibration by Mechanical Loads, Fuel Cells 16, No.1, 126-134

4. https://upload.wikimedia.org/wikipedia/commons/6/63/Proton_Exchange_Fuel_Cell_Diagram.svg

5. Shah R. K., (2003), Heat Exchangers for Fuel Cell Systems", The 4th International conference on Island, Greece.

6. Faghri A., and Guo Z., (2005), Challenges and opportunities of thermal management issues related to fuel cell technology and modeling, International Journal of Heat and Mass Transfer, vol. 48, pp. 3891-3920

7. Faghri A., and Guo Z., (2008), Integration of Heat Pipe into Fuel Cell Technology, Heat Transfer Engineering, vol. 29, 2008, pp. 232-238

8. Laughton M. A., (2002), Fuel cells, Power Eng J, 16:37-47

9. Hashmai S. M., (2010), Cooling Strategies for PEM FC Stacks, Msc. Thesis.

10. Incropera, F. P., Dewitt, D. P., Bergman, T. L., and Lavine, A. S., (2007), Fundamentals of heat and mass transfer, $6^{\text {th }}$ edition, John Wiley $\&$ Sons, Inc.

11. Alshorman A. A., (2014), Numerical Modeling and Investigation of PEM Fuel Cell for Performance Augmentation -Journal of Energy and Power Engineering 8, 857-869

12. Alshorman A. A., (2012), PEM Fuel Cell Investigation for Performance Enhancement", The $2^{\text {nd }}$ International Conference on Renewable Energy, Generation and Applications-ICREGA2012, United Arab Emirates University- March 4-7, Al Ain-UAE

13. Alshorman A. A, (2016), Characteristic Study of Bio-Membrane PEM Fuel Cell for 
Performance Upgrading, Procedia Computer Science Jr. 83,2016, 839 - 846

14. Yao K., et. al., (2004), A review of mathematical models for hydrogen and direct methanol polymer electrolyte membrane fuel cells. Fuel Cells 4(1-2), 3-29

15. Nowdeh S. A.,Nasrollahnejad M. B., Khayyatzadeh M., and SinaKashani S, (2012), Analysis of Effective Parameters of a PEMFC Considering Optimal Operation, Research Journal of Applied Sciences, Engineering and Technology 4(22): 4845-4850

16. Pukrushpan J. T, Peng A.G., (2002), Modeling and control for PEM fuel cell stack system. American Control Conference, Proceedings of the 2002, 4:3117-3122

17. Barbir F., (2005), PEM fuel cells: theory and practice. Amsterdam: Elsevier Academic Press

18. SetarehShahsavaria, Andrew Desouzab, MajidBahramia, Erik Kjeang , (2012), Thermal analysis of air-cooled PEM fuel cells, International journal of hydrogen energy 37, 18261 -18271 